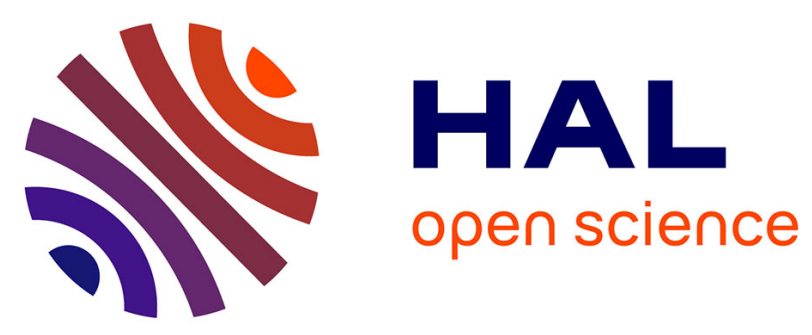

\title{
Proteomic Analysis of Human Whole and Parotid Salivas Following Stimulation by Different Tastes
}

\author{
Eric Neyraud, Thierry Sayd, Martine Morzel, Eric Dransfield
}

\section{To cite this version:}

Eric Neyraud, Thierry Sayd, Martine Morzel, Eric Dransfield. Proteomic Analysis of Human Whole and Parotid Salivas Following Stimulation by Different Tastes. Journal of Proteome Research, 2006, 5 (9), pp.2474-2480. 10.1021/pr060189z . hal-02884661

\section{HAL Id: hal-02884661 \\ https://hal.inrae.fr/hal-02884661}

Submitted on 30 Jun 2020

HAL is a multi-disciplinary open access archive for the deposit and dissemination of scientific research documents, whether they are published or not. The documents may come from teaching and research institutions in France or abroad, or from public or private research centers.
L'archive ouverte pluridisciplinaire HAL, est destinée au dépôt et à la diffusion de documents scientifiques de niveau recherche, publiés ou non, émanant des établissements d'enseignement et de recherche français ou étrangers, des laboratoires publics ou privés.

\section{(ㅇ)(1) $\$$}

Distributed under a Creative Commons Attribution - NonCommercial - NoDerivatives $\mid 4.0$ 


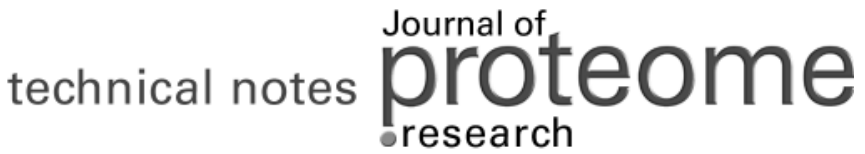

\section{Proteomic Analysis of Human Whole and Parotid Salivas Following Stimulation by Different Tastes}

\author{
Eric Neyraud, ${ }^{\dagger, \ddagger}, \$$ Thierry Sayd, ${ }^{\ddagger}$ Martine Morzel, ${ }^{\ddagger}$ and Eric Dransfield ${ }^{*, \dagger}$ \\ Wageningen Centre for Food Sciences, Diedenweg 20, PO Box 557, 6700 AN Wageningen, The Netherlands, \\ Biochimie et Protéines du Muscle, Qualité des Produits Animaux, INRA, 63122 Saint Genès-Champanelle, \\ France, and TNO, Utrechtseweg 48, PO Box 360, 3700 AJ Zeist, The Netherlands
}

Received April 25, 2006

\begin{abstract}
Whole and parotid salivas, collected after stimulation with tastants, were analyzed by $2 \mathrm{D}$ electrophoresis and mass spectrometry. In whole saliva, the number of proteins affected by taste stimulation increased in the order sweet < umami < bitter < acid. Annexin A1 and calgranulin $A$, involved in inflammation, were overrepresented after umami, bitter, and sour stimulations. Their low abundance or absence in parotid saliva after bitter stimulation suggested that they originated from other oral glands or tissues.
\end{abstract}

Keywords: human $\bullet$ saliva $\bullet$ parotid $\bullet$ taste $\bullet$ two-dimensional electrophoresis $\bullet$ mass spectrometry

\section{Introduction}

Human saliva is an aqueous complex mixture of proteins and minerals and has several physiological roles. It contributes to maintaining the oral cavity integrity by its lubricating, antibacterial, and buffering actions and acts in the first step of digestion by its incorporation of $\alpha$-amylase and lipase into the food bolus. ${ }^{1}$ Saliva is also important in food perception, as it is the medium through which taste is perceived.

Oral fluid, referred to as "whole saliva", is composed mainly of salivas from the contra-lateral major (parotid, submandibular, sublingual) and minor salivary glands and also of gingival crevicular fluids. Oral bacteria and food residues also form significant parts of oral fluid. ${ }^{2}$

Protein composition of saliva has been of interest for many years, ${ }^{3}$ and knowledge has advanced, especially during the past decade, with the development of new and powerful proteomics techniques for protein separation and identification. Only a few comparative proteomic studies on oral fluid have been performed and their main aim has been to derive diagnostic tools for health. ${ }^{4,5}$

The quantity and composition of oral fluid are known to be affected by food and taste stimulants. For example, the flow and bicarbonate concentration of saliva are increased during stimulation by acids, ${ }^{6}$ but little is known of any specific changes in protein patterns following taste stimulation. The aim of this

\footnotetext{
* To whom correspondence should be addressed. E-mail: eric.dransfield@ wur.nl.

${ }^{\dagger}$ Wageningen Centre for Food Sciences.

‡ INRA.

§ TNO.
}

study was to explore if the nature of a tastant stimulus modifies the proteome of saliva and to determine the origin (mucosa, salivary glands, gingival crevices) of any such modifications. For this, comparisons were made of salivary proteome at low and at high levels of four basic tastes and from whole and parotid saliva following a bitter taste.

\section{Materials and Methods}

Subjects and Rating of Taste Intensity. Saliva came from four healthy subjects. Each subject was given $1 \mathrm{~mL}$ of a low and high concentration of tastant. For sweetness, the low level was a solution of $0.38 \mathrm{M}$ and the high $1.5 \mathrm{M}$ glucose, for umami, 0.004 and $0.17 \mathrm{M}$ inosine monophosphate (IMP), for bitterness, 0.008 and $0.08 \mathrm{M} \mathrm{Ca}\left(\mathrm{NO}_{3}\right)_{2}$, and for sourness 0.002 and $0.07 \mathrm{M}$ $\mathrm{HNO}_{3}$ respectively. Sensory intensity ratings were given on a nonstructured line and scored subsequently from 0 to 100 with increasing intensity. Salty taste, also at two concentrations (of solutions of $\mathrm{NaCl}$ ), was included in the experimental design, but the resulting whole saliva did not give satisfactory eletrophoretic gels, and so the results from salt taste are not included.

Saliva Samples Collection. In a first series of experiments, whole saliva was collected after stimulation by tastants. The solution was kept in the mouth for $15 \mathrm{~s}$, and then was spat out, weighed, and immediately stored at $-80{ }^{\circ} \mathrm{C}$ until experimental use. The amount of saliva obtained was expressed as the weight of spit minus the weight $(1 \mathrm{~g})$ of solution administered. Each experiment was repeated the morning and the afternoon of the same day.

In a second series of experiments, whole and parotid saliva was collected after stimulation by bitterness. Because of an excellent reproducibility of gel patterns between the morning and the afternoon salivas found in the first series of analyses, samples were collected only once in the morning. The solution (2.5 mL) was injected into the mouth with a syringe and kept in the mouth for $4 \mathrm{~min}$. During this time, parotid saliva from one of the two parotid glands was collected using laboratorymade Lashley cups. After $4 \mathrm{~min}$, whole saliva was spat out. This saliva contained oral fluids and saliva from the one parotid gland without Lashley cup. Salivas were immediately stored at $-80{ }^{\circ} \mathrm{C}$ until experimental use.

Protein Extraction. After thawing at $4{ }^{\circ} \mathrm{C}$, samples were subjected to two centrifugations at $10^{\circ} \mathrm{C}(700 \mathrm{~g}$ for $2 \mathrm{~min}$ and then $14000 \mathrm{~g}$ for $30 \mathrm{~min}$ ). The supernatant was collected, and DTT (to $0.12 \% \mathrm{w} / \mathrm{v}$ ) was added. Proteins were precipitated overnight at $-20^{\circ} \mathrm{C}$ by addition of TCA in acetone $(1 \mathrm{~g} / \mathrm{mL})$ to 
a final concentration of $10 \%$ TCA. After a further centrifugation at $14000 \mathrm{~g}$ for $1 \mathrm{~h}$ at $4{ }^{\circ} \mathrm{C}$, the supernatant was discarded. The pellet was washed twice by adding $1 \mathrm{~mL}$ of cold acetone $/ 0.2 \%$ (w/v) DTT, homogenizing in a glass bead agitator (Retsch, Haan, Germany) for $15 \mathrm{~min}$ at $4{ }^{\circ} \mathrm{C}$, resting for $1 \mathrm{~h}$ at $-18^{\circ} \mathrm{C}$ and then centrifuging at $14000 \mathrm{~g}$ for $1 \mathrm{~h}$. The pellet was finally solubilized in $125 \mu \mathrm{L}$ of a buffer, consisting of $7 \mathrm{M}$ urea, $2 \mathrm{M}$ thiourea, $2 \%(\mathrm{w} / \mathrm{v})$ CHAPS, $0.1 \%(\mathrm{v} / \mathrm{v})$ proteases inhibitor cocktail (Bio-Rad), 1\% (w/v) DTT, and 0.4\% (v/v) 3-10 carrier ampholytes (Bio-Rad). Protein concentration was measured using the RC-DC kit (Bio-Rad).

Two-Dimensional Electrophoresis (2DE). Samples were subjected to isoelectric focusing (IEF) using 7-cm immobilized pH (3-10) gradient strips (Bio-Rad) on a PROTEAN (Bio-Rad) IEF cell. The protein load was adjusted to $50 \mu \mathrm{g}$. Samples were applied to strips by the gel reswelling method that lasted overnight at $20^{\circ} \mathrm{C}$. Focusing was performed at a final voltage of $2500 \mathrm{~V}$ for a total of $18000 \mathrm{Vh}$. Strips were subsequently equilibrated in two successive solutions of $6 \mathrm{M}$ urea, $2 \%(\mathrm{w} / \mathrm{v})$ SDS, $30 \%(\mathrm{v} / \mathrm{v})$ glycerol, $50 \mathrm{mM}$ Tris $\mathrm{pH} 8.8$, to which had been added either DTT at $1 \%(\mathrm{w} / \mathrm{v})$ or $2.5 \%$ iodoacetamide $(\mathrm{w} / \mathrm{v})$. Strips were finally applied to $12 \%$ SDS-polyacrylamide gels. Migration was conducted at a constant current of $15 \mathrm{~mA}$ per gel at $110 \mathrm{~V}$. To ensure a comparable background staining, two 7 -cm strips were placed adjacently onto a $17-\mathrm{cm}$ polyacrylamide gel. The two strips corresponded, in the first series of analyses, to the two concentrations of tastant for one subject, one time of sampling (morning or afternoon) and one taste. In the second series of analyses, the two strips placed on the same gel corresponded to whole and parotid saliva for the same subject. Gels were silver stained. ${ }^{7}$

Protein Identification. Spots of interest were manually excised using pipet tips. Spots were destained in $100 \mu \mathrm{L}$ of 30 $\mathrm{mM}$ potassium ferricyanide $-100 \mathrm{mM} \mathrm{Na}_{2} \mathrm{~S}_{2} \mathrm{O}_{3}$ for $2 \mathrm{~min}$ and rinsing in water. They were washed in $25 \mathrm{mM} \mathrm{NH}_{4} \mathrm{HCO}_{3}-5 \%$ acetonitrile (ACN) for $30 \mathrm{~min}$ and twice in $25 \mathrm{mM} \mathrm{NH}_{4} \mathrm{HCO}_{3}$ in ACN, each for $30 \mathrm{~min}$. Dehydration was initiated by adding $100 \%$ ACN for a few minutes. Further complete drying was performed using a speed vac RC10.22 (Jouan, St Herblain, France). The dry gel volume was evaluated and three volumes of $10 \mathrm{ng} / \mu \mathrm{L}$ trypsin (V5111, Promega, USA) in $25 \mathrm{mM} \mathrm{NH}_{4} \mathrm{HCO}_{3}$ were added. Digestion was performed at $37{ }^{\circ} \mathrm{C}$ overnight. Peptides were collected by adding $8 \mu \mathrm{L}$ of $100 \%$ ACN, sonicating for $5 \mathrm{~min}$ and rapid centrifugation.

For MALDI-TOF analysis, $0.9 \mu \mathrm{L}$ of supernatant was loaded directly onto the MALDI target. The same volume of matrix solution ( $5 \mathrm{mg} / \mathrm{mL}$ CHCA in $50 \%$ ACN $/ 0.1 \%$ TFA) was added immediately and allowed to dry at room temperature. Mass spectra were acquired on a Voyager DE-Pro MALDI-TOF spectrometer in positive-ion reflector mode. Monoisotopic masses were assigned and used for searches within the NCBI $\mathrm{nr}$ (no taxonomy restriction) database with the Mascot software (http://www.matrixscience.com). Carbamidomethyl modification of cysteine residues and oxidation of methionine residues were allowed, and searches were performed with a mass tolerance of $25 \mathrm{ppm}$.

When identification by MALDI-TOF was unsuccessful, further attempts were made using nano-LC-ion-trap MS/MS analysis. HPLC was performed with an ultimate LC system combined with Famos autosample and Switchos II microcolumn switching for preconcentration (LC Packings, Amsterdam, The Netherlands). The supernatant $(6 \mu \mathrm{L})$ containing peptides was loaded on the column PEPMAP C18, $5 \mu \mathrm{m}, 75 \mu \mathrm{m}$ ID, 15 cm (LC Packings) using a preconcentration step in a micro precolumn cartridge ( $300 \mu \mathrm{m}$ ID, $1 \mathrm{~mm}$ ). Supernatants were loaded on the precolumn at $30 \mu \mathrm{L} / \mathrm{min}$. After $3 \mathrm{~min}$, the precolumn was connected with the separating column and the gradient was started at $200 \mathrm{~nL} / \mathrm{min}$. The buffers were $5 \% \mathrm{ACN}$, $0.5 \% \mathrm{HCOOH}$ in water (A) and $5 \% \mathrm{H}_{2} \mathrm{O}, 0.5 \% \mathrm{HCOOH}$ in ACN (B). A linear gradient from 10 to $90 \% \mathrm{~B}$ for $45 \mathrm{~min}$ was applied. For ion-trap MS, a LCQ deca with a nano electrospray interface (Termofinnigan, Les Ulis, France) was used. Ionization $(2 \mathrm{kV}$ ionization potential) was performed with a liquid junction and a noncoated capillary probe (New Objective, Cambridge, USA). Peptide ions were analyzed by the data-dependent "triple play" method: (i) full MS scan $(m / z 400-2000)$, (ii) zoomscan (scan of the major ion with bigger resolution), (iii) MS/MS of this ion. Identification of peptides was performed with Bioworks 3.1, within the Swiss-Prot/Trembl protein database. Identifications of dicharged peptides were considered successful when Xcorr was above 2.0 and visual inspection proved a satisfactory correlation between experimental and theoretical MS/MS spectra.

Image Analyses and Statistical Treatment of Data. Gel images were acquired through a GS-800 densitometer and analyzed using PDQuest software (Bio-Rad). Gels were grouped into so-called "matchsets" in the following manner: for the first series of analyses, a matchset consisted of the 16 gels produced for four subjects, two concentrations of tastants, two replicates (morning and afternoon). Four matchsets were therefore constituted, one for each taste studied. In the second series of analyses, the matchset consisted of all eight gels produced for four subjects and the two sampling sites (whole and parotid). Spots were matched and quantified, and the average background noise was subtracted. Data were normalized by dividing each spot quantity by the total quantity of all valid spots. These relative quantities were expressed in ppm. When duplicate sampling had been performed, the average of the two quantities corresponding to the same spot was calculated. Data were finally subjected to a one-way ANOVA to determine the statistical significance, at the $5 \%$ level, of either the tastant concentration or the sampling site, in the first and second series of analyses, respectively.

\section{Results}

Taste Perception. The mean sensory intensity $( \pm S D)$ ratings on a scale of 100 were respectively for sweetness, umami, bitterness, and sourness: $10.9 \pm 6.0,13.4 \pm 8.4,9.1 \pm 4.6$, and $12.6 \pm 9.9$ at low concentration and $80.3 \pm 15.7,67.4 \pm 31.5$, $80.1 \pm 19.8$, and $93.6 \pm 13.1$ at high concentration of tastants.

Weight of Whole Saliva. The mean salivations $( \pm S D)$ in $\mathrm{g} / \mathrm{min}$ were respectively for sweetness, umami, bitterness, and sourness: $0.36 \pm 0.25,0.56 \pm 0.39,0.45 \pm 0.36$, and $0.94 \pm 0.37$ at low concentration and $0.81 \pm 0.49,0.56 \pm 0.37,0.71 \pm 0.48$, and $1.23 \pm 0.94$ at high concentration of tastants.

Whole Saliva Protein Pattern and Gel Reproducibility. Typical 2D electrophoretic profiles of whole saliva after stimulation at high level of each tastant are shown in Figure 1. Spots (120-130) were matched and quantified across the four-subject set of gels, depending on the taste. Within subject and stimulus, gel patterns from saliva collected in the morning were very similar to those from saliva collected in the afternoon, as shown in Figure 2. In contrast, clear differences appeared between subjects. An example of between-subject variability is arrowed in Figure 2. 

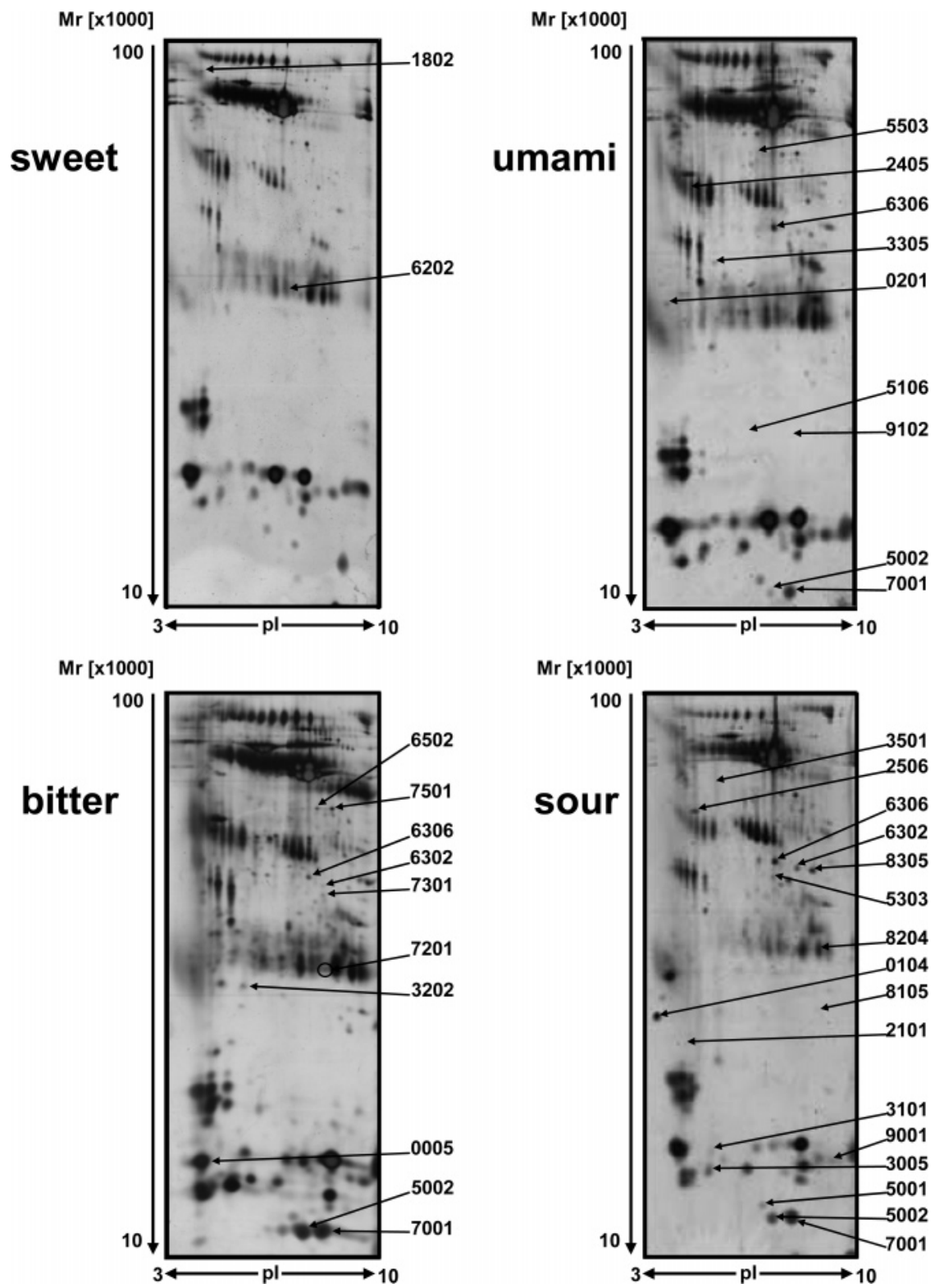

Figure 1. Two-dimensional electrophoretic profile of human whole saliva (pH gradient $3-10,12 \%$ acrylamide gel). The gel-scans shown were derived from salivas collected after tasting solutions of $1.5 \mathrm{M}$ glucose (sweet); $0.17 \mathrm{M} \mathrm{IMP}$ (umami); $0.08 \mathrm{M} \mathrm{Ca}\left(\mathrm{NO}_{3}\right)_{2}(\mathrm{bitter}) ;$ and $0.07 \mathrm{M} \mathrm{HNO}_{3}$ (sour). The quantities of those spots indicated by arrows were significantly $(p<5 \%)$ modified after stimulation at a high concentration of the given tastant.

Modifications of Protein Patterns in Whole Saliva after Chemical Stimulation. Quantities of 2, 9, 10, and 16 spots were significantly altered between the low and the high concentration of tastants for the tastes "sweet", "umami", "bitter", and "sour", respectively. Relative quantities and identification of such spots, when available, is provided in Table 1. Positions of significantly differently expressed spots between the two levels of the bitter stimulus are indicated in Figure 1.

Protein Patterns in Parotid and Whole Saliva after Application of a Bitter Stimulus. An example of a gel of parotid saliva is shown in Figure 3. It differs visibly from that of whole saliva (Figure 1) by its less complex protein composition. Ten spots were over-represented compared to whole saliva collected under similar conditions, and two proteins (PRH2 protein and carbonic anhydrase VI) were identified. Forty-four spots were over-represented in whole saliva and four proteins (cystatin S, annexin A1, enolase 1, IGHG1 protein = IgG1) were identified.
Table 2 shows relative quantities, in parotid and whole saliva, of those spots that had been previously found to be significantly altered after stimulation by a bitter stimulus at a high level in whole saliva (see Table 1). Spots 5002, 6306, and 7301, which were overexpressed after stimulation at a high concentration of bitter tastant, were not detectable in parotid saliva. All other spots were present but at a lower relative quantity in parotid saliva compared to whole saliva. This was validated statistically for spots 3202, 6302, 6502, and 7501 .

\section{Discussion}

The description of saliva proteome is currently being explored through the development of high-resolution separation and identification techniques. For example, 2DE has recently been used to describe the proteome of human whole saliva ${ }^{8-10}$ or of gland specific salivas. ${ }^{11,12}$ Other techniques, such as one or two-dimensional liquid chromatography coupled to mass 

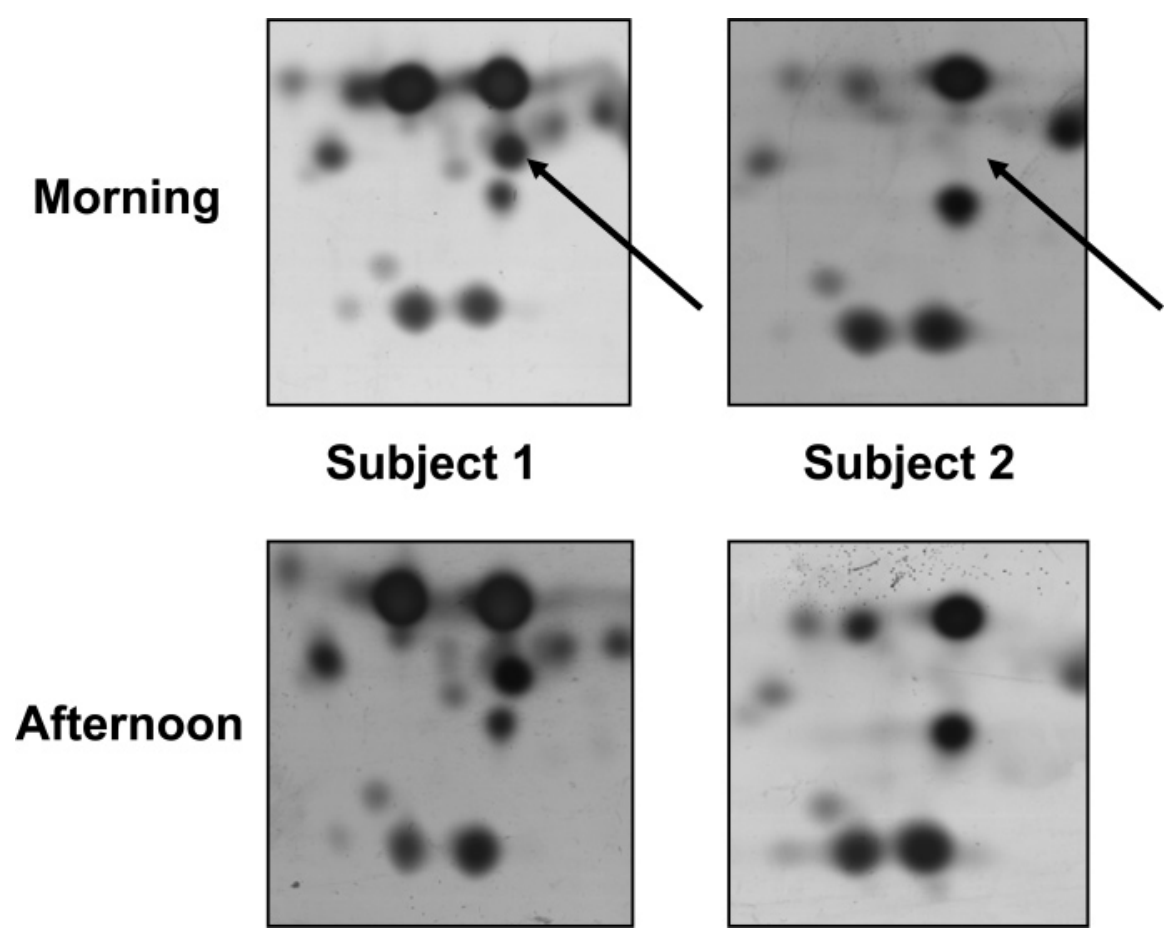

Figure 2. Zoom of a region $(\mathrm{p} / \approx 6-9 ; \mathrm{Mr} \approx 12-16000)$ of whole saliva $2 \mathrm{DE}$ gels, illustrating within-subject low variation in protein pattern in saliva was collected in the morning and in the afternoon under the same stimulation $\mathrm{conditions}\left(0.08 \mathrm{M} \mathrm{Ca}\left(\mathrm{NO}_{3}\right)_{2}\right)$. The arrow indicates an example of between-subject variations.

spectrometry have also been applied to tentatively decipher the entire protein composition of saliva. ${ }^{13-15}$ Chromatographybased methods can overcome some limitations inherent to 2DE, for example in the difficulty of observing proteins with high molecular weight or with basic pI. However, quantification is difficult with chromatography-based methods.

A comparative 2DE study reported by Huang ${ }^{4}$ showed differences in the saliva proteome among subjects with or without tooth decay. In the present study, on healthy volunteers with no obvious oral pathology or salivary dysfunctions, the protein patterns also differed between subjects. In contrast, we observed a very consistent pattern of proteins between morning and afternoon saliva samples collected under similar conditions, at least for those observed on gels $(\mathrm{MW} \approx 10-100 \mathrm{kDa}$, $\mathrm{p} I 3-10)$. This is particularly noteworthy because saliva flow and composition are affected by circadian variations ${ }^{2}$ and protein concentration appears to be highest in late afternoon. ${ }^{16}$

Between-subject variations in salivary protein pattern may depend on an individual's physiological status (age, medical condition, dental and oral health), but do not interfere with the purpose of this study, which was to evaluate the impact of an external taste stimulus on saliva protein composition. The interaction of saliva and taste, reviewed by Spielman, ${ }^{17}$ has been so far studied mainly through the effect of tastants on saliva flow and ionic composition. ${ }^{18,19}$ For example, sour taste induces a high salivary flow, ${ }^{20}$ which we confirmed here, and generally, the proportion of parotid saliva in whole saliva increases with increase in salivary flow. ${ }^{2}$ In contrast, little is known about protein composition in saliva when stimulated by tastants. Spielman $^{21}$ reported that the relative proportion of proline-rich proteins (PRPs) was unaffected by four basic tastes, whereas Gjorstrup $^{22}$ described elevated $\alpha$-amylase concentrations in rabbit saliva after administration of citric acid. Becerra ${ }^{23}$ also reported variations in several enzymes ( $\alpha$-amylase, carbonic anhydrase, peroxidase) after a complex stimulation induced by fruit flavored candies.

In the present study, with less than 5 min taste stimulation, any proteome modifications would probably result from the release of proteins from preformed vesicles and not from de novo synthesis, which in pancreatic exocrine cells takes about $30 \mathrm{~min}$ to pass from the rough endoplasmic reticulum to the condensing vacuoles. ${ }^{24}$

We observed that the protein patterns of whole saliva were affected differently according to the nature of the taste, sweetness producing little change. Two proteins, calgranulin A and annexin A1, were common to the other 3 tastes (umami, bitterness, and sourness) with their high abundancy in saliva induced by exposure to the tastants at high concentration. Calgranulin A, also called MRP8 or S100 A8, is a calciumbinding protein which plays a major role in inflammatory and immunological responses. ${ }^{25}$ Its cytokine activity ${ }^{26}$ has been associated with inflammatory reactions in bowel, ${ }^{25}$ skin, ${ }^{26}$ or oral tissues. ${ }^{27,28}$ Concerning annexin A1, also known as lipocortin 1 , it is a cytosolic calcium-binding protein and binds to cellular membranes in the presence of calcium ions. ${ }^{29}$ Although its function has not been clearly defined, it appears to be involved in vesicular trafficking and fusion, ${ }^{30}$ and it has been suggested to possess anti-inflammatory properties in vitro. ${ }^{31}$ It is induced in lung tumors ${ }^{32}$ or during exposure to smokeless tobacco in Hamster cheek pouch epithelium cells. ${ }^{33}$ Thus, taken together, the over-representation of calgranulin A and annexin Al seems to point to a mechanism whereby exposure to molecules eliciting umami, bitter, and sour tastes would trigger an inflammatory-like response, probably through the release of preformed proteins as mentioned above. Furthermore, the response appears stronger when the stimulus was more "aversive". Two other proteins identified in saliva further enforce this hypothesis. These were annexin A2 and beta-2-microglo- 
Table 1. List of Spots Whose Representation Is Significantly Different in Saliva Stimulated at Two Concentrations of Tastants ${ }^{a}$

\begin{tabular}{|c|c|c|c|c|c|}
\hline \multirow[b]{2}{*}{ taste } & \multirow[b]{2}{*}{ spot number } & \multirow[b]{2}{*}{ identification } & \multirow[b]{2}{*}{ reference } & \multicolumn{2}{|c|}{ Quantity (ppm) } \\
\hline & & & & low concentration of tastant & high concentration of tastant \\
\hline sweetness & $\begin{array}{l}1802 \\
6202\end{array}$ & ni & & $\begin{array}{r}3568 \\
10033\end{array}$ & $\begin{array}{l}1662 \\
5339\end{array}$ \\
\hline umami & $\begin{array}{l}0201 \\
3305 \\
\mathbf{5 0 0 2 / 7 0 0 1} \\
5106 \\
\mathbf{6 3 0 6} \\
9102 \\
2405 \\
5503\end{array}$ & $\begin{array}{l}\text { ni } \\
\text { ni } \\
\text { calgranulin A } \\
\text { ni } \\
\text { annexin A1 } \\
\text { ni } \\
\text { ni } \\
\text { ni }\end{array}$ & $\begin{array}{l}\text { gi| } 30583595 \\
\text { gi| } 55959292\end{array}$ & $\begin{array}{c}1173 \\
622 \\
\mathbf{6 2 9} / \mathbf{5 8 8 9} \\
0 \\
\mathbf{0} \\
90 \\
14786 \\
2838\end{array}$ & $\begin{array}{l}5900 \\
2484 \\
\mathbf{6 0 2 2 / 3 9 4 0 1} \\
303 \\
\mathbf{6 0 5 8} \\
773 \\
6630 \\
1495\end{array}$ \\
\hline bitterness & $\begin{array}{l}\mathbf{5 0 0 2 / 7 0 0 1} \\
\mathbf{6 3 0 6} \\
7301 \\
0005 \\
3202 \\
\mathbf{6 3 0 2} \\
6502 / 7501 \\
7201\end{array}$ & $\begin{array}{l}\text { calgranulin A } \\
\text { annexin A1 } \\
\text { ni } \\
\text { cystatin S } \\
\text { ni } \\
\text { ni } \\
\text { enolase } 1 \\
\text { ni }\end{array}$ & $\begin{array}{l}\text { gi| } \mathbf{3 0 5 8 3 5 9 5} \\
\text { gi| } \mathbf{5 5 9 5 9 2 9 2} \\
\text { gi| } 9971054 \\
\text { gi| } 62896593\end{array}$ & $\begin{array}{c}\mathbf{1 5 7 1 / 1 5 8 2 4} \\
\mathbf{0} \\
296 \\
67412 \\
3701 \\
\mathbf{5 7 8} \\
5725 / 9662 \\
4652\end{array}$ & $\begin{array}{c}\mathbf{2 3 8 1 5} / \mathbf{4 7 4 8 6} \\
\mathbf{1 7 3 7} \\
680 \\
27392 \\
1593 \\
\mathbf{6 8} \\
901 / 1089 \\
1245\end{array}$ \\
\hline sourness & $\begin{array}{l}0104 \\
3005 \\
3501 \\
\mathbf{5 0 0 2 / 7 0 0 1} \\
5303 \\
\mathbf{6 3 0 2} \\
\mathbf{6 3 0 6} \\
8305 \\
2101 \\
2506 \\
3101 \\
5001 \\
8105 \\
8204 \\
9001\end{array}$ & $\begin{array}{l}\text { PRH2 protein: acidic PRP } \\
\text { ni } \\
\text { alpha-amylase (chain X) } \\
\text { calgranulin A } \\
\text { ni } \\
\text { ni } \\
\text { annexin A1 } \\
\text { annexin A2 } \\
\text { ni } \\
\text { ni } \\
\text { ni } \\
\text { beta-2-microglobuline } \\
\text { ni } \\
\text { ni } \\
\text { ni }\end{array}$ & 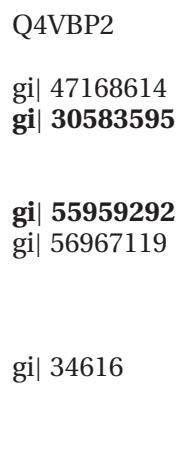 & $\begin{array}{c}0 \\
0 \\
0 \\
\mathbf{1 8 9 7 / 1 7} \mathbf{1 7 7} \\
0 \\
\mathbf{5 2 5} \\
\mathbf{7 5 6} \\
431 \\
2572 \\
23171 \\
5004 \\
4938 \\
1259 \\
36651 \\
13758\end{array}$ & $\begin{array}{c}7049 \\
2339 \\
16380 \\
\mathbf{2 7} \mathbf{6 0 5 / 4 6 ~ 8 3 6} \\
1397 \\
\mathbf{2 4 6 0} \\
\mathbf{8 8 2 4} \\
3592 \\
0 \\
9012 \\
752 \\
3251 \\
0 \\
20362 \\
4401\end{array}$ \\
\hline
\end{tabular}

${ }^{a} \mathrm{Ni}$ : not identified. Spots common to at least two tastes are given in bold. When two spot numbers corresponded to the same protein, the 2 spot numbers and respective relative quantities are given together on the same line.

bulin, and their quantity was augmented after a strong "sourness" stimulus. Annexin A2 is highly homologous to annexin Al with respect to association into polymers or $\mathrm{Ca}^{2+}$ dependent membrane-binding properties, ${ }^{30}$ which lead us to suppose that they have close biological functions. As for beta-2-microglobulin, increased levels have been reported in saliva in the cases of autoimmune disorders ${ }^{34,35}$ and in juvenile periodontitis. ${ }^{36}$ Therefore, over-representation of these two proteins after a strong sour taste again suggests an association with an immunological-type reaction.

Reduction in relative quantities of cystatin S and enolase 1 after a strong bitter stimulation are probably linked to other mechanisms. Cystatin S has been repeatedly reported to be present in whole saliva. ${ }^{37,38}$ Although a member of a family of cysteine proteinase inhibitors ${ }^{39}$ and generally overexpressed during inflammation, cystatin S has only a poor protease inhibitory activity compared with other cystatins. Its high hydroxyapatite and calcium-binding properties suggest a specialized role for this protein in tooth mineralization. ${ }^{40,41} \mathrm{Re}$ duced quantities may result from adsorption onto tooth enamel. Concerning enolase 1 , present in saliva ${ }^{12,15}$ and less represented in whole saliva of patients suffering from oral bleeding, ${ }^{4}$ its function in the oral cavity is unknown, and the link between bitter stimulation and decreased enolase 1 remains unclear.

Finally, the higher abundance of PRH2 protein (acidic PRP) and $\alpha$-amylase in whole saliva after stimulation by a sour tastant at high concentration was probably the consequence of an increased parotid salivary flow. Thus, one gene product of PRH2, with comparable apparent MW and $\mathrm{p} I$ to the one we report, was specifically found in parotid saliva. ${ }^{12}$ Similarly, $\alpha$-amylase is predominantly secreted from parotid glands. ${ }^{2}$

The subsequent comparison between whole saliva and parotid saliva after stimulation by bitterness was designed to provide indications of the tissue (parotid glands/other salivary glands/mucosa/gingival crevices) at the origin of the modifications described above. As already mentioned, higher abundance of acidic PRP and $\alpha$-amylase after a strong sourness stimulation resulted from a higher proportion of parotid saliva in whole saliva. The other identified proteins involved in inflammationlike reactions, whose quantity was significantly increased after taste stimulation, came most probably from other sources. Thus, calgranulin A is detected in whole saliva but not in parotid or submandibular/sublingual saliva. ${ }^{12}$ We found that annexin Al was over-represented in whole saliva, indicating a mainly nonparotid origin, which is consistent with the production of annexin A1 by cultured oral epithelial cells. ${ }^{33}$ Beta-2microglobulin is also detected in oral mucosal transudates. ${ }^{35}$ It appears consequently that these anti-inflammatory compounds were released from oral tissues (mucosa, gingival crevices) other than the parotid.

More specifically, all the proteins that we had found differentially represented after stimulation with a bitter tastant were less abundant in parotid saliva, which rules out a significant 


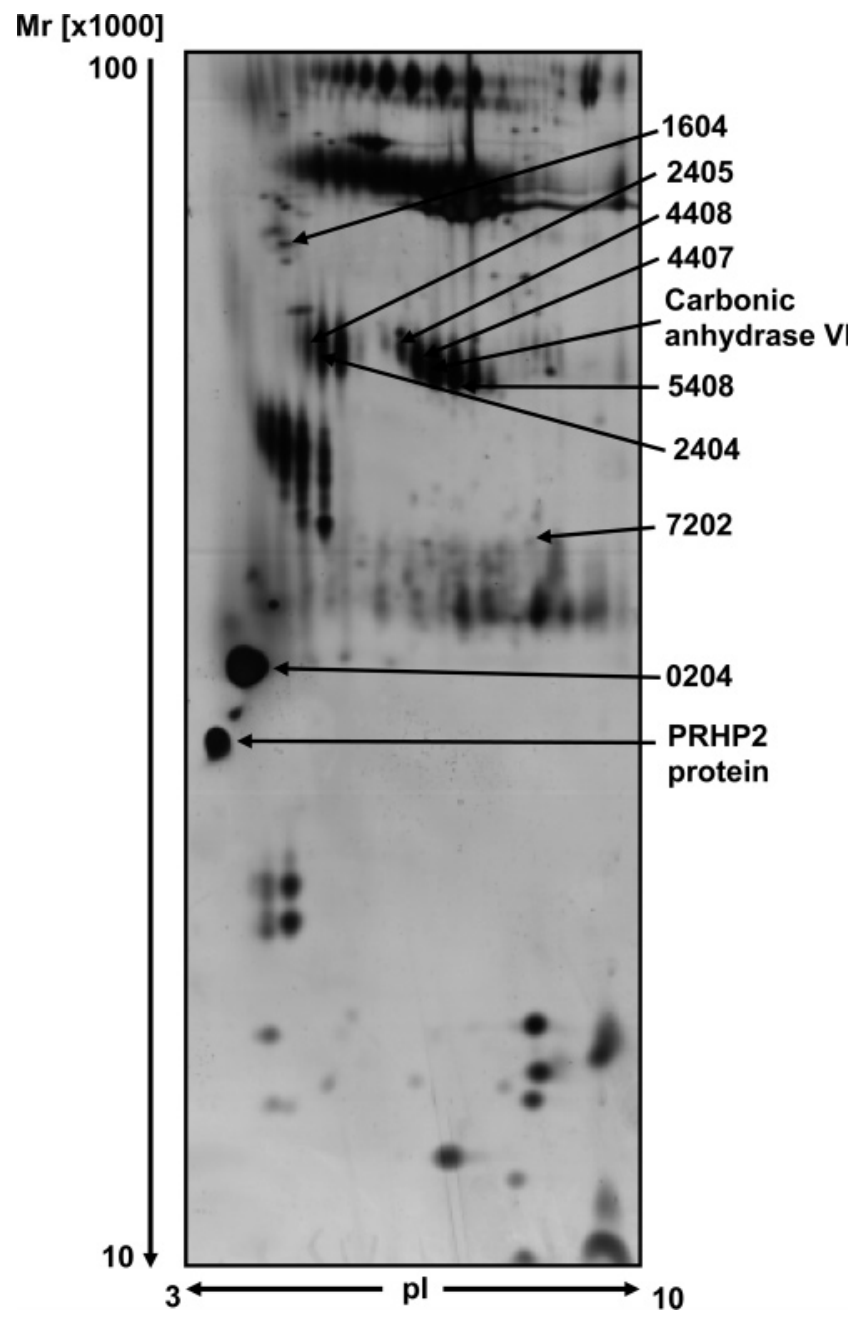

Figure 3. Two-dimensional electrophoretic profile of human parotid saliva ( $\mathrm{pH}$ gradient $3-10,12 \%$ polyacrylamide gel) collected during application of a bitter stimulus. Labeled spots were over-represented in parotid saliva compared to whole saliva.

Table 2. Relative Quantities, in Whole Saliva (WS) and in Parotid Saliva (PS) after Stimulation by Bitterness, of Spots Whose Representation Was Significantly Different in Whole Saliva Stimulated at Two Concentrations of $\mathrm{Ca}\left(\mathrm{NO}_{3}\right)_{2}$ Solution ${ }^{a}$

\begin{tabular}{clrr}
\hline & & \multicolumn{2}{c}{ relative quantity $(\mathrm{ppm})$} \\
\cline { 3 - 4 } spot number & identification & \multicolumn{1}{c}{ WS } & \multicolumn{1}{c}{ PS } \\
\hline 5002 & calgranulin A & 4401 & 0 \\
7001 & calgranulin A & 16490 & 1876 \\
6306 & annexin A1 & 484 & 0 \\
7301 & ni & 1211 & 0 \\
0005 & cystatin S & 50417 & 8126 \\
3202 & ni & 3522 & 539 \\
6302 & ni & 903 & 170 \\
6502 & enolase 1 & 7012 & 508 \\
7501 & enolase1 & 5935 & 1431 \\
7201 & ni & 2713 & 1651
\end{tabular}

${ }^{a}$ In the upper part, proteins were over-expressed at high tastant concentration and in the lower part, proteins were under-expressed at high tastant concentration

contribution of parotid gland to the modifications of whole saliva for this particular taste.

To summarize, stimulation by tastes modified the whole saliva proteome. Sweetness, a palatable taste, had close to no effect on saliva proteome, whereas more aversive tastes induced a greater disturbance in protein patterns. With the exception of the sour taste, which induced a major increase in $\alpha$-amylase, the changes in whole saliva were mainly due to action of the tastants on the oral mucosa, gingival crevices, or salivary glands other than the parotid.

Acknowledgment. We thank Cathrine Karlsson (WCFS, The Netherlands) for collection of saliva and Christophe Chambon (proteomic platform, INRA, Theix, France) for identification of proteins.

\section{References}

(1) Pedersen, A. M.; Barlow, A.; Jensen, S. B.; Nauntofte, B. Oral Dis. 2002, 8, 117-129.

(2) Humphrey, S. P.; Williamson, R. T. J. Prosthet. Dent. 2001, 85, 162-169.

(3) Ellison S. A. In Handbook of physiology. Section 6. Alimentary canal; Williams \& Wilkins: Baltimore, 1967.

(4) Huang, C. M. Arch. Oral Biol. 2004, 49, 951-962.

(5) Ryu, O. H.; Atkinson, J. C.; Hoehn, G. T.; Illei, G. G.; Hart, T. C. Rheumatology 2006, in press.

(6) Schneyer L. H.; Schneyer C. A. In Handbook of physiology. Section 6. Alimentary canal; Williams \& Wilkins; Baltimore, 1967.

(7) Yan, J. X.; Harry, R. A.; Spibey, C.; Dunn, M. J. Electrophoresis 2000, 21, 3657-3665.

(8) Ghafouri, B.; Tagesson, C.; Lindahl, M. Proteomics 2003, 3, 10031015.

(9) Vitorino, R.; Lobo, M. J.; Ferrer-Correira, A. J.; Dubin, J. R.; Tomer K. B.; Domingues, P. M.; Amado, F. M. Proteomics 2004, 4, 11091115.

(10) Hu, S.; Xie, Y.; Ramachandran, P.; Ogorzalek Loo, R. R.; Li, Y.; Loo, J. A.; Wong, D. T. Proteomics 2005, 5, 1714-1728.

(11) Hardt, M.; Thomas, L. R.; Dixon, S. E.; Newport, G.; Agabian, N. Prakobphol, A.; Hall, S. C.; Witkowska, H. E.; Fisher, S. J. Biochemistry 2005, 44, 2885-2899.

(12) Walz, A.; Stühler, K.; Wattenberg, A.; Hawranke, E.; Meyer, H. E.; Schmalz, G.; Blüggel, M.; Ruhl, S. Proteomics 2006, 6, 1631-1639.

(13) Messana, I.; Loffredo, F.; Inzitari, R.; Cabras, T.; Giardina, B.; Onnis, G.; Piludu, M.; Castagnola, M. Eur. J. Morphol. 2003, 41, 103-106.

(14) Messana, I.; Cabras, T.; Inzitari, R.; Lupi, A.; Zuppi, C.; Olmi, C.; Fadda, M. B.; Cordaro, M.; Giardina, B.; Castagnola, M. J Proteome Res. 2004, 3, 792-800.

(15) Wilmarth, P. A.; Riviere, M. A.; Rustvold, D. L.; Lauten, J. D.; Madden, T. E.; David, L. L. J. Proteome Res. 2004, 3, 1017-1023.

(16) Rudney, J. D. Crit. Rev. Oral Biol. Med. 1995, 6, 343-367.

(17) Spielman, A. I. J. Dent. Res. 1990, 69, 838-843.

(18) Watanabe, S.; Dawes, C. Arch. Oral Biol. 1988, 33, 1-5.

(19) Neyraud, E.; Prinz, J.; Dransfield, E. Physiol. Behav. 2003, 79, 731737.

(20) Chauncey, H. H.; Feller, R. P.; Henriques, B. L. J. Dent. Res. 1966 , 45, 1230.

(21) Spielman, A. I.; Ph.D. Thesis, University of Toronto, Toronto; 1988

(22) Gjorstrup, P. Acta Physiol. Scand. 1980, 110, 295-301.

(23) Becerra, L.; Soares, R. V.; Bruno, L. S.; Siqueira, C. C.; Oppenheim, F. G.; Offner, G. D.; Troxler, R. F. Arch. Oral Biol. 2003, 48, 147154.

(24) Palade, G. Science 1975, 189, 347-358.

(25) Lugering, N.; Stoll, R.; Schmid, K. W.; Kucharzik, T.; Stein, H.; Burmeister, G.; Sorg, C.; Domschke, W. Eur. J. Clin. Invest. 1995, 25, 659-664

(26) Kelly, S. E.; Jones, D. B.; Fleming, S. J. Pathol. 1989, 159, 17-21.

(27) Kojima, T.; Andersen, E.; Sanchez, J. C.; Wilkins, M. R.; Hochstrasser, D. F.; Pralong, W. F.; Cimasoni, G. J. Dent. Res. 2000 , 79, 740-747.

(28) Lundy, F. T.; Chalk, R.; Lamey, P. J.; Shaw, C.; Linden, G. J. J Pathol. 2000, 192, 540-544.

(29) Gerke, V.; Moss, S. E. Physiol. Rev. 2002, 82, 331-371.

(30) Patel, D. R.; Isas, J. M.; Ladokhin, A. S.; Jao, C. C.; Kim, Y. E.; Kirsch, T.; Langen, R.; Haigler, H. T. Biochemistry 2005, 44, 28332844

(31) Cirino, G.; Peers, S. H.; Flower, R. J.; Browning, J. L.; Pepinsky, R. B. Proc. Natl. Acad. Sci. U.S.A. 1989, 86, 3428-3432. 
(32) Oh, P.; Li, Y.; Durr, E.; Krasinska, K. M.; Carver, L. A.; Testa, J. E. Schnitzer, J. E. Nature 2004, 429, 618-619.

(33) Vishwanatha, J. K.; Swinney, R.; Banerjee, A. G. Mol. Cell Biochem. 2003, 248, 67-75.

(34) van der Geest, S. A.; Markusse, H. M.; Swaak, A. J. Ann. Rheum. Dis. 1993, 52, 461-463.

(35) Nishanian, P.; Aziz, N.; Chung, J.; Detels, R.; Fahey, J. L. Clin. Diagn. Lab. Immunol. 1998, 5, 507-512.

(36) Akalin, F. A.; Bulut, S.; Yavuzilmaz, E. J. Nihon. Univ. Sch. Dent. 1993, 35, 230-234.

(37) Baron, A.; Barrett-Vespone, N.; Featherstone, J. Oral Dis. 1999 , $5,344-353$.
(38) Lupi, A.; Messana, I.; Denotti, G.; Schinina, M. E.; Gambarini, G.; Fadda, M. B.; Vitali, A.; Cabras, T.; Piras, V.; Patamia, M.; Cordaro, M.; Giardina, B.; Castagnola, M. Proteomics 2003, 3, 461-467.

(39) Henskens, Y. M.; Veerman, E. C.; Nieuw Amerongen, A. V. Biol. Chem. Hoppe Seyler 1996, 377, 71-86.

(40) Dickinson, D. P. Crit. Rev. Oral Biol. Med. 2002, 13, 238-275.

(41) Vitorino, R.; Lobo, M. J.; Duarte, J.; Ferrer-Correia, A. J.; Tomer, K. B.; Dubin, J. R.; Domingues, P. M.; Amado, F. M. Biochem. Biophys. Res. Commun. 2004, 320, 342-346.

PR060189Z 